\title{
An Unusual Association of Pyoderma Gangrenosum with Henoch-Schonlein Purpura in a Child
}

\author{
Bir Çocuk Hastada Piyoderma Gangrenozum ile Henoch-Schönlein Purpurasının \\ Alışılmadık Birlikteliği
}

\author{
Nilgün Selçuk Duru, Melike İrem Petan, Hale Sandıkçı Suiçmez*, Murat Elevli, \\ Özgür Kasapçopur ** \\ University of Health Sciences Haseki Training and Research Hospital, Clinic of Pediatrics, Istanbul, Turkey \\ *Keçiören Training and Research Hospital, Clinic of Pediatrics, Ankara, Turkey \\ **istanbul University Cerrahpaşa Faculty of Medicine, Department of Pediatrics, Division of Pediatric Rheumatology, Istanbul, Turkey
}

\begin{abstract}
Henoch-Schonlein purpura (HSP) is a systemic vasculitis affecting small vessels. Pyoderma gangrenosum (PG) is an uncommon, non-infectious, neutrophilic dermatosis. A sixteen-year-old boy was admitted to our clinic with arthralgia, palpable purpuric rush and a wound on the left lower extremity. Dermatological examination revealed an ulcer $3 \times 3 \mathrm{~cm}$ in diameter covered with necrotic material and surrounded by a bluish ring. The lesion was found to be clinically compatible with pyoderma gangrenosum. Histological examination of the biopsy material taken from the purpuric rush was compatible with leukocytoclastic vasculitis. Direct immunofluorescence showed IgA class antibody and C3 deposition within the dermal capillaries. These findings were suggestive of HSP. We report a case of HSP with PG like ulcer. To the best of our knowledge, only one adult case of HSP with PG has been reported so far.
\end{abstract}

Keywords: Henoch-Schonlein purpura, pyoderma gangrenosum, scin ulcer, vasculitis
Öz

Henoch-Schönlein purpurası (HSP) küçük damarları etkileyen bir sistemik vaskülitdir. Piyoderma gangrenozum (PG) ise nadir rastlanan, enfeksiyöz olmayan bir nötrofilik dermatozdur. On altı yaşındaki erkek hasta kliniğimize artralji, palpabl purpura ve sol alt ekstremite üzerinde bir yara ile başvurdu. Dermatolojik muayenesinde tabanı nekrotik materyal ile kaplı, mavimsi bir halka ile çevrili $3 \times 3 \mathrm{~cm}$ çapında bir ülser gözlendi. Lezyon klinik olarak PG ile uyumlu bulundu. Purpurik döküntüden alınan biyopsi materyalinin histolojik incelemesi lökoklastik vaskülit ile uyumluydu. Direkt immünofluoresans dermal kapillerler içinde IgA sınıfı antikorlar ve C3 depolanmaları gösterdi. Bulgular HSP tanısı ile uyumluydu. Bilgilerimize göre şimdiye kadar PG ile birlikte HSP olgusu yalnız bir erişkin hastada sunulmuştur.

Anahtar Sözcükler: Henoch-Schönlein purpura, piyoderma gangrenozum, deri ülseri, vaskülit

of PG depends on clinical findings. Histological findings are nonspecific $(1,2)$. Henoch-Schönlein purpura (HSP) is an acute small-vessel vasculitis that including the triad of palpable purpura, abdominal pain and arthritis (3).

In this paper, we present a patient who had PGlike lesions and was diagnosed as having HSP. To our knowledge, there is no report of association of PG with HSP in children.
Address for Correspondence/Yazışma Adresi: Nilgün Selçuk Duru University of Health Sciences Haseki Training and Research Hospital, Clinic of Pediatrics, Istanbul, Turkey Phone: +90 2125294400 E-mail: nilgunduru@yahoo.com Received/Geliş Tarihi: 28 June 2016 Accepted/Kabul Tarihi: 29 August 2016 This case report was presented at the "3. Çocuk Dostları' Congress as a poster. e Copyright 2017 by The Medical Bulletin of University of Health Sciences Haseki Training and Research Hospital The Medical Bulletin of Haseki published by Galenos Yayınevi. 'Telif Hakkı 2017 Sağlık Bilimleri Üniversitesi Haseki Eğitim ve Araş̧ırma Hastanesi Haseki Tıp Bülteni, Galenos Yayınevi tarafından basılmıştır. 


\section{Case}

A sixteen-year-old boy presented to the hospital with the complaints of arthralgia, purpuric rush involving both the lower extremities and a painful skin lesion on the left leg for the past few days. The skin lesion had started four days ago as a vesiculopustular lesion and progressed to a painful necrotic ulcer. There was no history of drug intake. There was no similar history in the past. Family history was unremarkable.

At the time of admission, the clinical condition of the patient was good. On examination, he was afebrile. His vital parameters were within the normal limits and anthropometric measurements were normal. There were no joint swellings. Dermatological examination showed maculopapular rushes (Figure 1) on both the lower extremities and buttocks, and a large ulcer about $3 \times 3 \mathrm{~cm}$ in diameter on the lower one-third of the left leg (Figure 1,2 ). The floor was covered with necrotic tissue and the surrounding skin was erythematous and edematous. The edges of the lesion were well defined, and pale to bluish in color. Within 36 hours from admission, two small necrotic lesions occurred over the left food and on the lower leg and, then, they progressed to ulcer (Figure 3, 4).

Complete blood count, C-reactive protein, erythrocyte sedimentation rate, prothrombin time and partial thromboplastin time were within the normal ranges. Analyses of serum biochemical test, immunoglobulin profile and complement levels were all within the normal limits. Rheumatoid factor, antiphospholipid antibodies, antinuclear antibodies and antineutrophil cytoplasmic antibodies were undetectable. Urine examination was also normal. Fecal occult blood test was negative. Serological assays of $\lg \mathrm{M}$ and $\lg \mathrm{G}$ specific for Epstein-Barr, Parvovirus, and anti-Hepatitis $C$ virus were negative. Hepatitis surface antigen was negative and HIV test using enzyme-linked immunosorbent assay was non-reactive. Ig $\mathrm{G}$ and $\mathrm{M}$ specific for mycoplasma pneumoniae were found to be positive. His blood culture did not grow any organism. There was no pathologic finding on his abdominal ultrasound and chest roentgenogram. No pathological findings were observed on Doppler ultrasound. Pathergy test was positive. The clinical appearance of the lesion was consistent with PG. Dermatologic consultation confirmed the diagnosis. Consultation with pediatric surgery revealed no additional abnormalities. Fecal calprotectin concentration was found to be within the normal levels and anti-Saccharomyces cerevisiae antibodies were negative. A biopsy from a purpuric lesion was also performed and the histological findings were compatible with leukocytoclastic vasculitis. Direct immunofluorescence showed granular deposition of $\lg$ A and C3 in the walls of the small blood vessels of the dermis.

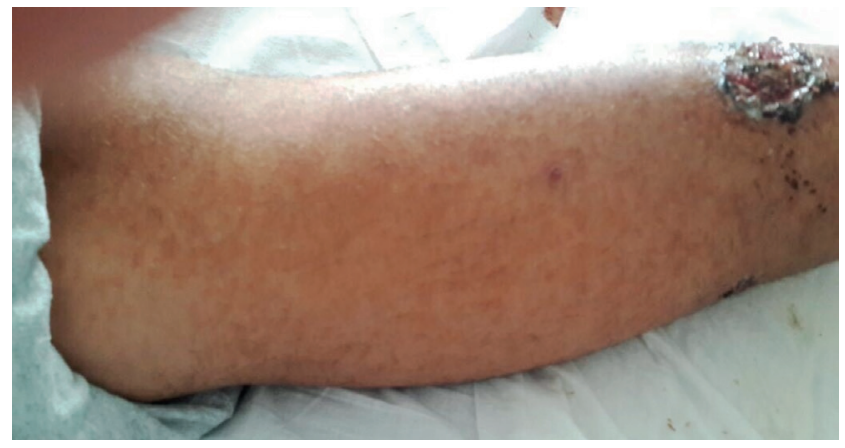

Figure 1. Maculopapular purpuric rash and an ulcerative lesion on the left lower extremity

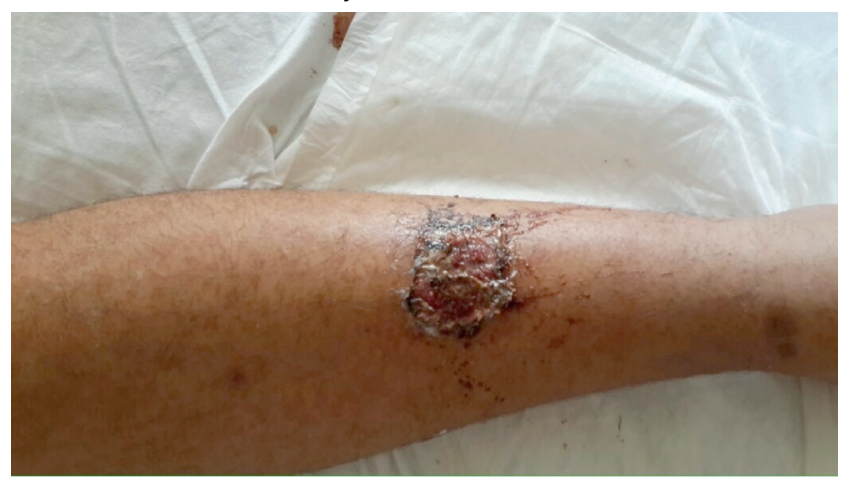

Figure 2. Ulcerative lesion of pyoderma gangrenosum measuring $3.0 \times 3.0 \mathrm{~cm}$ on the lower one-third of left leg

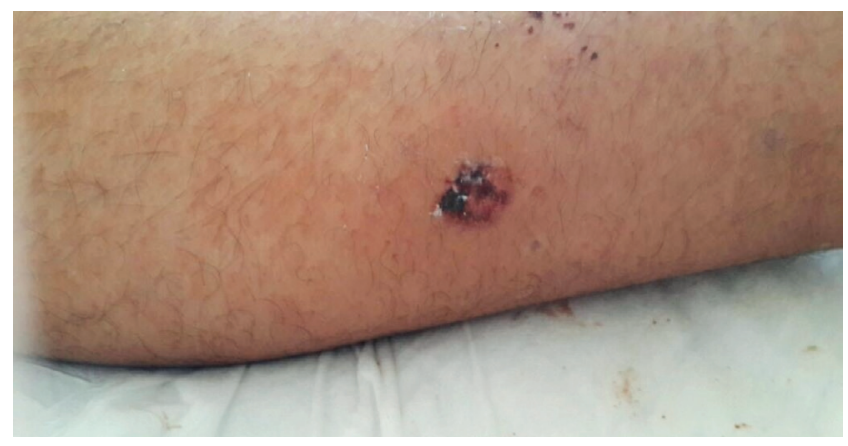

Figure 3. A small necrotic lesion on the medium of lower leg

During the admission period, the child presented stability of the clinical condition but the lesions were painful. The patient was started on prednisolone $60 \mathrm{mg} /$ day and clarithromycin $15 \mathrm{mg}$ daily. Within three weeks, the inflammation dramatically subsided. The lesion gradually healed, and prednisone was tapered on the 30th day and completely stopped after 15 days. He remained hospitalized for six weeks and he was discharged and recommended to receive periodic urinalysis for six months. During the follow-up, the child was in excellent condition, and the skin lesions disappeared without new lesions. Fecal occult blood and urine examination were negative during the follow-up and the child did not present any relapse of the disease during the follow-up period. 


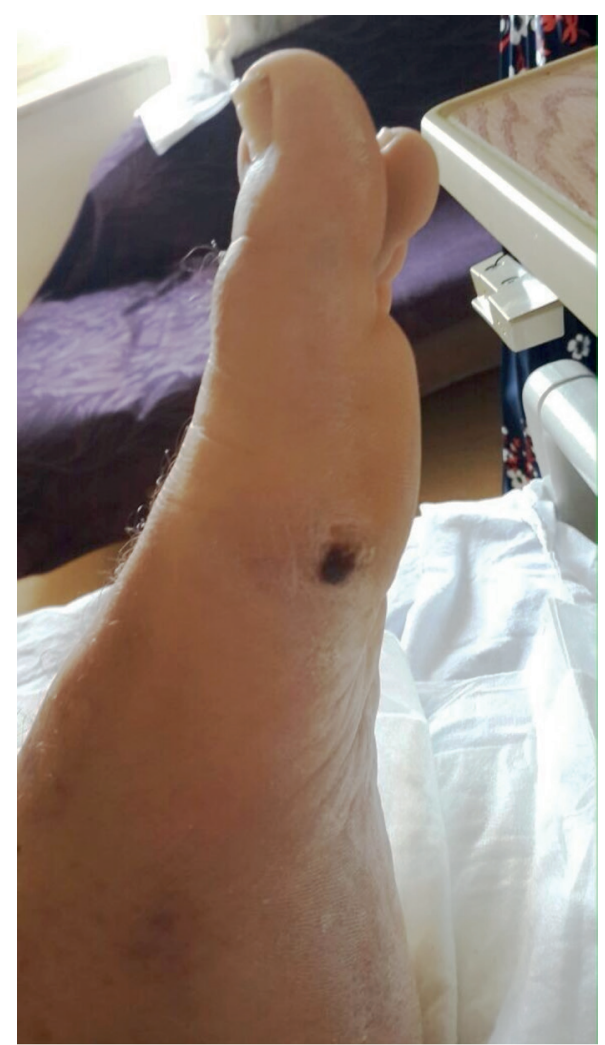

Figure 4. A small necrotic lesion over the left food

\section{Discussion}

The incidence of PG is between three and ten per million per year. It is seen in the fourth to fifth decade of life but can occur at any age. Only $4 \%$ of all cases have been reported in children and infants $(1,2)$.

Since its first description in 1930, the etiology of PG has remained unknown $(1,4)$. The diagnosis of $P G$ is difficult and bases on the clinical signs. However, diagnostic criteria have been established (5). Diagnosis requires the presence of two major criteria and at least two minor criteria.

Major criteria:

1) Rapid progression of a painful, necrotic, cutaneous ulcer.

2) Exclusion of other causes of ulcerative cutaneous disorders.

Minor criteria:

1) History suggestive of pathergy or clinical findings of cribriform scarring.

2) Underlying systemic disease.

3) Histopathologic findings (sterile dermal neutrophilia, mixed inflammation, lymphocytic vasculitis).

4) Rapid response to systemic steroid treatment. Our patient presented with a painful, necrotic ulcer. Within 36 hours of admission, two new lesions occurred and then they rapidly progressed to ulcer. He had no history of insect bite. The blood and wound cultures were sterile. The pathergy test was found to be positive. Neutrophilic inflammation was not observed in the skin biopsy; the biopsy specimens were taken only from a purpuric rush. The lesions healed with steroid treatment. These findings were compatible with the diagnosis of PG.

PG in children may develop with various conditions, including ulcerative colitis more frequently. Other conditions associated with PG include leukemia, IgA monoclonal gammopathy, Crohn's disease, rheumatoid arthritis, Takayasu's arteritis, Behçet's disease and various immunodeficiencies, including HIV infection, chronic granulomatous disease, and hyper IgE syndrome. However, about $50 \%$ of those affected by PG have no underlying disorder $(1,4)$. Signs and symptoms of known underlying disorders were absent in our patient.

However, clinical and histological findings in the patient were compatible with HSP. Criteria for identifying HSP were established by the American College of Rheumatology in 1990 and adopted by the European League Against Rheumatism (EULAR)\Paediatric Rheumatology International Trials Organisation (PRINTO) \Paediatric Rheumatology European Society (PRES) in 2008 (6). Our patient fulfilled four criteria (palpable purpura, young age, arthralgia/arthritis and leukocytoclastic vasculitis) of the American College of Rheumatology and three criteria (palpable purpura, arthralgia/arthritis, leukocytoclastic vasculitis) of the EULAR\PRINTO\PRES. Therefore, he was diagnosed with PG associated with HSP.

Samuel et al. (7) reported an adult patient who had PG-like lesions and was diagnosed as having HSP. To our knowledge, ours is the first documented case of PG associated with HSP in a child.

\section{Conclusion}

We reported this patient who had the clinical features of PG associated with HSP to draw attention to the coexistence of these two diseases. Diagnosis of PG may be difficult. Early recognition may prevent unnecessary surgical treatment which may lead to dangerous complications.

\section{Ethics}

Informed Consent: A consent form was completed by all participants.

Peer-review: Externally and internally peer-reviewed.

\section{Authorship Contributions}

Surgical and Medical Practices: N.S.D., M.I.P., H.S.S., Ö.K. Concept: N.S.D. Design: N.S.D., M.E. Data Collection or Processing: N.S.D., M.i.P. Analysis or Interpretation: N.S.D., Ö.K. Literature Search: N.S.D., H.S.S., M.I,P. Writing: N.S.D. 
Conflict of Interest: No conflict of interest was declared by the authors.

Financial Disclosure: The authors declared that this study received no financial support.

\section{References}

1. Lambropoulos V, Patsatsi A, Tsona A, Papakonstantinou A, Filippopoulos A, Sotiriadis D. The adverse consequences of pyoderma gangrenosum in a 13 year old child. Int J Surg Case Rep 2011;2:221-4.

2. Powell FC, Su WP, Perry HO. Pyoderma gangrenosum: Classification and management. J Am Acad Dermatol 1996;34:395-409.

3. Hong J, Yang HR. Laboratory markers indicating gastrointestinal involvement of henoch-schönlein purpura in children. Pediatr Gastroenterol Hepatol Nutr 2015;18:39-47.
4. Rani CS, Kiran AG, Vani DS, Devi EN. Indian J Dermatol Venereol Leprol 2015;81:548.

5. Su WP, Davis MD, Weenig RH, Powell FC, Perry HO. Pyoderma gangrenosum: clinicopathologic correlation and proposed diagnostic criteria. Int J Dermatol 2004;43:790-800.

6. Ozen S, Pistorio A, lusan SM, et al; Paediatric Rheumatology International Trials Organisation (PRINTO). Paediatric Rheumatology International Trials Organisation (PRINTO). EULAR/PRINTO/PRES criteria for Henoch-Schönlein purpura, childhood polyarteritis nodosa, childhood Wegener granulomatosis and childhood Takayasu arteritis: Ankara 2008. Part II: Final classification criteria. Ann Rheum Dis 2010;69:798-806.

7. Samuel S, Loftus EV, Sandborn WJ. Henoch-Schönlein Purpura in an Adult Mimicking Crohn's Disease and Pyoderma Gangrenosum. Dig Dis Sci 2011;56:2205-6. 